\title{
MANAGING PROCUREMENT OF FOOD WITH ADDED VALUE: A CASE STUDY OF BEEF IN THE CATERING SECTOR
}

\author{
Hanna Astner \\ Swedish University of Agricultural Sciences, Uppsala, Sweden \\ E-mail: Hanna.Astner@slu.se \\ Ingrid Stigzelius \\ Stockholm School of Economics, Stockholm, Sweden \\ E-mail: Ingrid.Stigzelius@hhs.se \\ Hans Andersson, Cecilia Mark-Herbert \\ Swedish University of Agricultural Sciences, Uppsala, Sweden \\ E-mail: Hans.Andersson@slu.se, Cecilia.Mark-Herbert@slu.se
}

\begin{abstract}
Consumers have limited options to choose food with added values in the catering market. Management challenges include making informed product portfolio decisions of what to offer the consumers. These decisions are based on procedures for procurement. The public procurement process is influenced by political objectives and a different set of laws compared to commercial procurement. This research project explores the management of procurement conditions for food products with added values; with a particular interest in beef in public and private restaurants. The results show that personal values of professional purchasers play a key role in the procurement decision. In the commercial sector, marketing of food with added values can provide opportunities for differentiation. In public procurement, opportunities for food with added values are influenced by politics and legislation. Main management obstacles perceived by catering units purchasing beef with added values are associated with lack of volumes, ineffective distribution and higher prices.
\end{abstract}

Key words: locally produced, meat, organic, private, public, procurement, purchase, restaurant, Sweden, value chain.

\section{Introduction}

Considerable interest is being directed toward growing awareness of creating added values in the food marketing chain. These added values are associated with a number of choices made in the value chain, for example with regard to the processing, production methods, geographical origin, packaging, aesthetics, marketing channels and other profiling properties. The production and consumption of food in general and beef in particular (Swedish Environmental Protection Agency, 2007) is constantly a topic for public debate, since it has been negatively associated with animal welfare, environmental effects, food safety and human health. In the public debate, organic beef production has been promoted as a more sustainable 
PROBLEMS

OF MANAGEMENT

IN THE $21^{\text {st }}$ CENTURY

Volume 2, 2011

lternative to conventional beef in terms of reduced environmental impact and improved animal welfare (KRAV, 2009). Geographical origin, in this case Swedish beef production, has also been promoted as contributing to an open landscape with positive effects on biodiversity (Swedish Environmental Protection Agency, 2008) and is often associated with stringent regulations on food safety and animal welfare (SLV, 2009). In this context organic as well as Swedish production constitutes production related grounds for added value for the Swedish consumer.

\section{Research Problem}

Beef production is one of the major food industries in Sweden and it is linked with the dairy industry (Delfi, 2006). In addition, the Swedish beef consumption has increased with 39 percent over the years 1995-2005 (Swedish Board of Agriculture, 2008). However, the imported share of beef has also increased and now constitutes 46 percent of the total market, which means that the increase in consumption does not correspond to an increase in national production (Delfi, 2006, 54). Imported beef is especially common in the commercial catering sector, where approximately 75 percent of the beef is imported (Delfi, 2006, 54). Despite the fact that nearly 70 percent of the Swedish consumers express a preference for Swedish food (SOU, 2005, 54) they are somehow unable to make the preferred choices in a restaurant or catering situation. The same situation applies to the catering market of organic food.

A majority of the Swedish consumers have positive attitudes towards organic food (Magnusson et al., 2001). In 2007 the organic food consumption increased with up to 30 percent (Swedish Ecological Farmers, 2008, 2) which amounts to around 3 percent of the total market. Political goals have been formulated to increase organic production and public consumption of organic products (Swedish Government, 2005). Thereby, the public sector is attempting to serve as a driving force for market development through its own consumption in public catering (Li \& Geiser, 2005). Nevertheless, the catering sector represents a rather limited share of the overall organic food market (17,5 percent) whereas the retailing sector has the largest market share (71 percent) (Swedish Ecological Farmers, 2008, 2). Hence, consumers have relatively limited options to choose food with an added value associated with environmental impact, animal welfare or geographical origin within the catering sector. This is a somewhat contradictive situation, since organic food and eating away from home represent two parallel trends in Sweden, where nearly half of all the meals are consumed outside the home (Post et al., 2008).

Recent studies reveal that consumers' ability to change food habits largely depend on the professional purchasers' decisions to provide alternatives (Bergström et al., 2005; Grankvist \& Biel, 2007; Inwood et al., 2009; Post et al., 2008). The available products to choose from for the professional purchaser are in turn determined by decisions in the wholesale sector (Grankvist \& Biel, 2007). In order to understand the conditions for purchasing food with added values in the catering sector, it is of vital importance to study the exchanges between buyers and suppliers in the catering-wholesaler relation. Nevertheless, relatively limited research has been conducted on the procurement conditions for supplying food with added value within the catering sector, including comparisons between conditions for public and commercial procurement (Walker et al., 2008).

\section{Research Aim}

The aim of this paper is to explore the procurement conditions for food products with added values offered in the catering-wholesaler relation. The paper focuses on obstacles and opportunities in promoting added values in beef products in the commercial and public catering sector. Two research questions of particular interest are: Which factors influence the procurement 
of beef? And, how do these factors differ between the public and commercial catering sectors? The results may be used to facilitate the understanding of the required conditions for promoting food products with added values, associated with, for example, the production method or the geographical origin.

\section{Theoretical Perspectives}

Conditions for procurement is determined by a large number of factors (Walker et al., 2008), both related to the relationship between the buyer and supplier (Easton, 1992) and the context in which they operate (Pfeffer \& Salancik, 2003). The selected perspective focuses on the buyer-supplier relationship, but it also offers explanatory value for external factors that neither of the actors control.

The Market-As-Network (MAN) approach offers a theoretical framework that focuses on the exchange relationship between industrial actors as an important mechanism for understanding buying behaviour in the supply chain (Turnbull et al., 1996). According to MAN, organizations are linked by short-term exchange episodes and long-term relationships (Ward \& Webster, 1991). Through the study of exchange relationships, it is possible to identify the network of actors that form the industrial system, and thereby examine the domain of recourses that are required and are subject to control by the actors. These resources are also used by the actors to add value in the process. Instead of the term supply chain Porter (1985) introduced the value chain concept to put focus on the value that a firm is creating for its customers. In a macro-business perspective the value chain concept is broadened to incorporate whole industries and all value-adding activities undertaken by the 'partners' in the network (Walters \& Lancaster, 1999), e. g. the value network (Pitta \& Laric, 2004). There are both horizontal and vertical networks in the food sector (Gellynck \& Kühne, 2010). However the main focus in this study is on vertical networks, where the terms value chain and value network are used synonymously to describe the relationships and value-adding activities throughout the network, which incorporates the company, suppliers, distributors and consumers.

Johanson and Mattsson (1992) distinguish the industrial system into two levels: 1) the network of exchange relationships between actors and 2) the production system where resources are used by the actors in production (Figure 1). The model offered by Johanson and Mattsson (1992) illustrates the two folded nature of the industrial system. The exchange relationships between actors are to be regarded as structures that govern the production system (Johanson \& Mattsson, 1992). Each of these actors controls certain resources in the network. However, interdependencies of the resources pose constraints on the individual actors (Easton, 1992). These constraints may also originate from pressures external to the organizations, which affect the negotiation powers in actor relationships (Pfeffer \& Salancik, 2003). The interdependencies create a network structure, which is characterized by bonds between the actors (Easton, 1992), e.g. economic, social, legal, political, technical and logistical bonds. Stable networks are characterized by strong social bonds where economic factors are somewhat less important. 


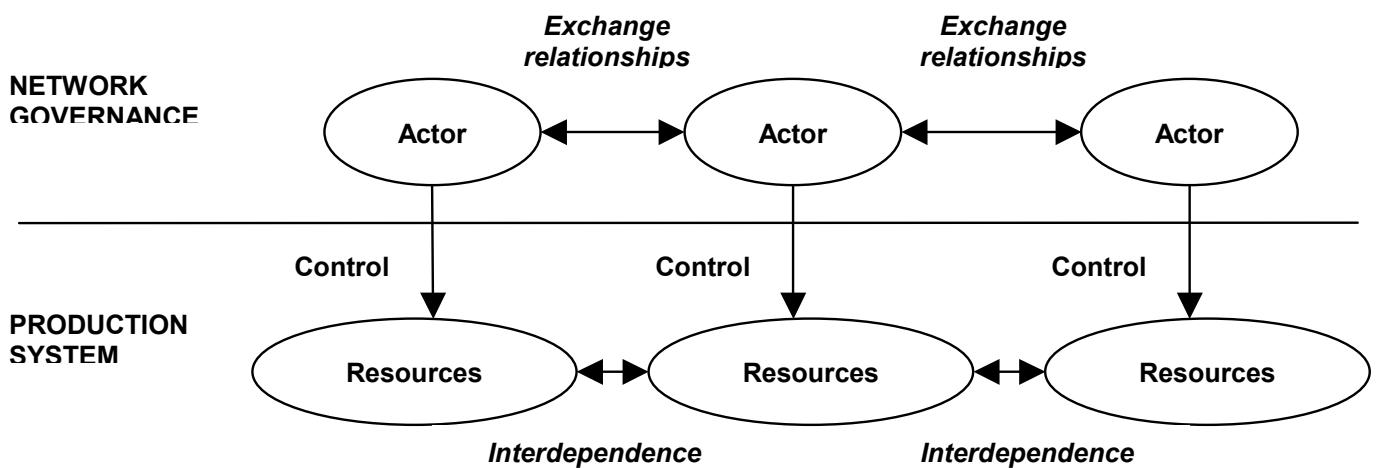

Figure 1: Network governance in the production system (Johanson \& Mattsson, 1992, 208).

The structures of industrial systems are heterogeneous, since there are varying needs that could be met in different ways by multi-dimensional resources (Easton, 1992). A firms' ability to transform the resources to meet the needs depends on factors that are specific to the firms' structure, e.g. history, investments, available resources, employee preferences and skills. Networks are therefore viewed as embedded in a local setting that is interactive with the society at large, e.g. politics and government (Mattsson \& Johanson, 2006). Pfeffer and Salancik (2003) also emphasize the importance of studying the external environment of organizations in order to fully understand the decision process. This study specifically examines the structure of the Swedish beef value network and its external environment, which provides a foundation for understanding the procurement decisions within catering organizations.

\section{Methodology of Research}

A study of conditions for procurement in a commercial and public setting offers several possible research perspectives. The chosen focus for this study is that of the relation between catering organizations and wholesalers in the procurement process. Given the relatively unexplored empirical field, especially in terms of comparisons of conditions for public and commercial procurement (Walker et al., 2008), the study is based on an exploratory approach using a flexible research design that allows for the research procedures to "unfold as the research proceeds" (Robson, 2002, 5).

\section{Research Design}

In a pilot study industry experts with expertise in management of procurement provided the starting points for developing an interview guide, which was complemented by a literature review and survey of public documents. The interview guide was semi-structured with openended questions and was focused around the four themes discussed below: 1) geographical origin of a product, 2) production methods, 3 ) product properties and 4) delivery services. The guide was adjusted to better fit the perspectives of the different interviewees in the main study. The selection criteria for interviewees were:

$>$ Organizations representing both public and commercial catering organizations and wholesalers for beef products

$>$ Catering organizations and wholesalers with different profiles and interests in food 
with added value

Individuals responsible for procurement at municipalities and persons managing selling and purchasing decisions at wholesalers and catering organizations

Although the catering sector consists of many different actors, the study was limited to find representatives from: day care centers, schools and homes for elderly; lunch catering and á la carte restaurants (Table 1). A variation in profiles and interests in food with added values was one of the key criteria in selecting procurement units. A division between lunch catering and á la carte was conducted in order to consider different price ranges. In total, 33 specialist stakeholders representing commercial and public catering organizations in the four largest cities in Sweden (Stockholm, Göteborg, Malmö and Uppsala) were interviewed.

\section{Table 1. Sources of information in gathering empirical material.}

\begin{tabular}{|l|l|}
\hline Procurement units (actors) & Number of interviewed actors (pronounced profile) \\
\hline Commercial catering & 5 (3 organic and local food) \\
\hline - Lunch restaurants & 7 (2 health, 1 towards Swedish meat) \\
\hline - Á la carte restaurants & \\
\hline Public catering & $\begin{array}{l}4 \text { (no clear profile, but all try to attain the goal for organic food and } \\
\text { facilitate for the possibility to buy Swedish food) }\end{array}$ \\
\hline - Municipality procurement department & $\begin{array}{l}3(1 \text { health \& environment, thought all favours Swedish and organic } \\
\text { beef) }\end{array}$ \\
\hline - Day care centres & $5(1$ organic and 1 towards Swedish meat) \\
\hline - School canteens & 4 (none with a pronounced profile) \\
\hline - Homes for elderly & 3 \\
\hline Wholesaler & 2 \\
\hline Experts & 33 \\
\hline Total & \\
\hline
\end{tabular}

Interviewees were given an opportunity to validate and clarify misunderstandings during the interview in a 'continuous validation procedure' (Robson, 2002). Despite of a delicate and careful validation process, the results are to be regarded as primary results. The study does not represent a statistically representative analysis of the entire catering sector as such, but rather provides a deeper understanding of specific conditions, which warrants some caution in generalizing the conclusions of the study.

\section{Institutional Context}

Previous studies of the beef value network have detected different quality attributes affiliated with the production and processing system, which contribute to an increased value of the product (Boland \& Schroeder, 2002). Meat products are fresh produce, which are characterized by direct links between primary production and the final products' quality attributes (Ziggers \& Trienekens, 1999). These links enhance the level of interdependence between different actors in the value network.

Consumers are increasingly demanding beef products associated with multiple quality attributes, e.g. organically grown beef or beef that is produced on small, local farms (Boland \& Schroeder, 2002; Grunert et al., 2004; Krystallis \& Chryssohoidis, 2005). Production method and geographical location of the farm thus serve as grounds for differentiation in a value network (Ziggers \& Trienekens, 1999; Boland \& Schroeder, 2002). 
PROBLEMS

OF MANAGEMENT

IN THE $21^{\text {st }}$ CENTURY

Volume 2, 2011
The Value Chain for Beef in Sweden

The value chain for beef is integrated into a simplified single strand chain that goes 'from farm to fork' (Figure 2). It focuses on actors that create quality attributes, i.e. value, through the transformation of resources. The figure illustrates the resources that are already transformed and thus constitute an input to the next actor in the value chain. The total value of the final product, i.e. the meal, is therefore closely connected to the resources that each actor in the value chain controls. In what follows, the actors and resources in the beef value chain are briefly described with comparisons between conventional and organic beef.

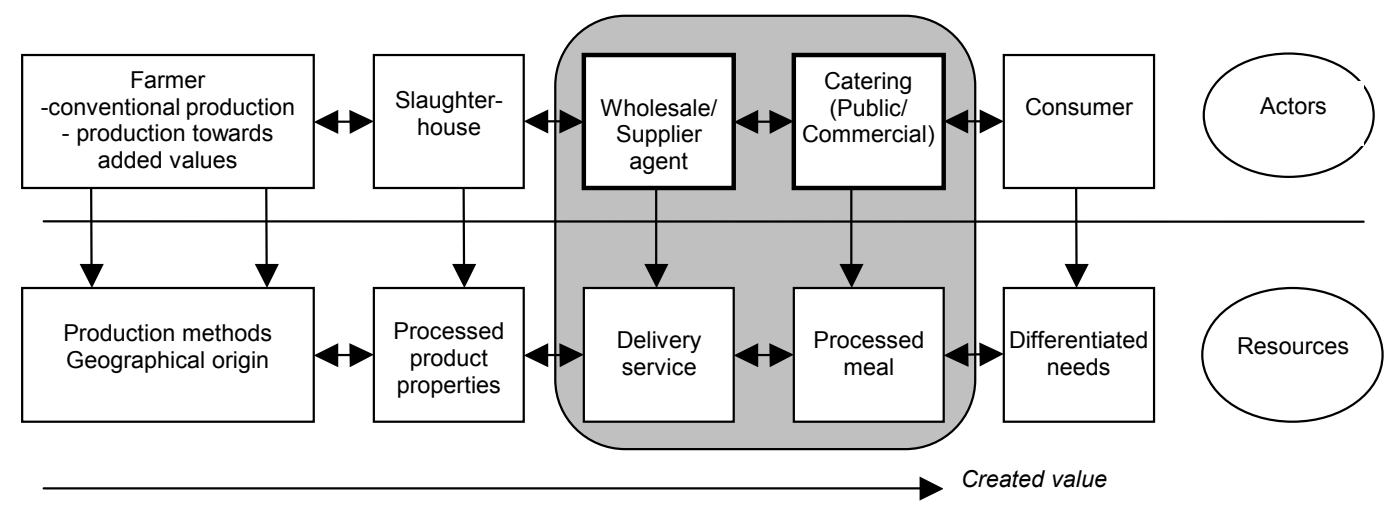

- - External environment (legal conditions, politics, institutional expectations, culture etc.)

Figure 2: A simplified model of actors and resources in a value chain of beef products for the public and commercial catering sectors. The focal exchange relationship, wholesale-catering, is marked with the shaded box.

In the value chain for beef products, the farmers control two important recourses for creating value in the beef product, that of the geographical origin and that of production method. Whether or not these attributes are communicated in the continued value chain is decided by the perception of creating value. In the value chain, consumers' perceptions serve as the guide lines for creating value. For example nearly 70 percent of the Swedish consumers display a great confidence in Swedish food production and consider it important that the food is produced in Sweden (SOU, 2005, 54). However, the country of origin is rarely revealed to the consumers within the catering sector where share of import is around 75 percent, whereas the import share rarely exceeds 30 percent in the retail sector (Delfi, 2006, 54). Nearly all of the consumed organic fresh meat in Sweden is also produced in Sweden (Swedish Ecological Farmers, 2008).

Another resource that is controlled by the farmer is the choice of production method (Figure 2). In Sweden, the market differs between conventional and organic production. Organic beef production is based on grazing and organic coarse feed produced without the use of pesticides and commercial fertilizers (KRAV, 2009). In contrast conventional beef production does not have to be based on organic course feed, and therefore mostly includes additional concentrates (Swedish Environmental Protection Agency, 2008). These different production methods can not only create product properties that could be perceived through taste, but also add psychologically perceived values associated with animal welfare and environmental aspects. 
In Sweden, KRAV (Association for Control of Organic Production) holds the most well-known organic production standard and has set up rules for the whole value chain from production to marketing with consumer oriented labels (KRAV, 2009). Certifications and private market oriented standards, such as KRAV, can invoke additional consumer trust for the farmer (Higgins et al., 2008).

The slaughterhouses control the product processing, where slaughter and tenderizing techniques are important for the quality of the product (Figure 2). In Sweden, one slaughter firm dominates the fresh meat market and accounts for 57 percent of the slaughtered volume. About 75 percent of the slaughtered organic beef is also channelled through this slaughterhouse (Swedish Ecological Farmers, 2008).

Wholesalers or more specialized suppliers control the deliveries of the processed product to the catering sector (Figure 2). These deliveries can be regarded as a service through which not only the product, but also knowledge of the product properties, is transferred to the catering sector. Swedish wholesaling is characterized by a high degree of concentration where a few actors dominate the market (Swedish Competition Authority, 2005; Delfi, 2006). Wholesale distribution is thus increasing at the expense of individual suppliers where direct distribution typically is losing ground. However, some producers supply directly to restaurants and retailers in an attempt to diversify and add values associated with for example organic and/or local production.

Public and commercial catering organizations control the meal processing of the beef product, which aims to fulfil the differentiated consumer needs (Figure 2). The public catering sector is managed by local and regional authorities and serves meals within schools, hospitals and homes for elderly (Bergström et al., 2005). It is characterized by relatively large production units and small serving units (Delfi, 2006, 32). The commercial catering sector is managed by entrepreneurs and has a wide spectrum of lunch and á la carte restaurants (Bergström et al., 2005). It is constituted by many small production and serving units (Delfi, 2006, 32).

Given this review of the beef value chain we are able to identify four major resources that, in addition to price and availability, potentially could affect the catering organizations' buying decisions: 1) geographical origin, 2) production methods, 3) product properties and 4) delivery services (Figure 2). The relative importance and influence of these resources in the buying decision are further examined in the context bound empirical analysis.

\section{External Environment}

The external environment (Pfeffer \& Salancik, 2003) such as legal conditions and institutional expectations constitute a framework for the value network of beef production (Figure 2). Swedish food legislation is regulated in the Food Act (SFS, 2006:804) that applies to all stages of production, processing and distribution of food (SLV, 2009). In addition to Swedish food legislation, the public catering sector adheres to the European directive on public procurement with the objective of providing firms the same competitive conditions throughout Europe (Swedish Competition Authority, 2008).

Political guidelines also provide an external influence on the actors (Bergström et al., 2005). The Swedish government has defined a goal to reach 25 percent organic public consumption before year 2010 (Swedish Government, 2005), which directs the public actors towards increasing purchases of organic food. However, each municipality or county council is responsible for implementing the goals by their own means. Such political goals do not exist concerning country of origin and locally produced food; if it did it would be considered an offence according to EC regulations. Nevertheless, use of environmental information in procurement has increasingly been recognized as an important factor for the choice of food products among professional purchasers (Grankvist \& Biel, 2007; Bergström et al., 2005). 
PROBLEMS

OF MANAGEMENT

IN THE $21^{\text {st }}$ CENTURY

Volume 2, 2011

26 These institutional expectations influence the exchanges between catering organizations and their suppliers.

\section{Wholesale-catering Exchange}

The relative interdependencies between a buyer and a supplier (Easton, 1992) are visible in the procurement process (Bergström et al., 2005). In public procurement, many small catering units conduct procurement agreements collectively through the municipality or county council, which normally involve large volumes over several years (Swedish Competition Authority, 2008). It enables the catering units to benefit from lower prices. While large scale wholesalers and catering units enter into business agreements, small scale food suppliers (that more often offer differentiated products with added value) are at disadvantage. Large volumes are typically required in answering to public food enquires and smaller companies may therefore not be able to enter the competitive bidding process. Nevertheless, it is legally possible for small scale food companies to enter the bidding process by splitting the enquiry so that several suppliers are able to respond (Swedish Competition Authority, 2008).

The commercial catering organizations have less bargaining power compared to the public sector (Delfi, 2006) and therefore face a weaker position relative to the large wholesalers. On the other hand, commercial catering units are not obliged to sign long term contracts to the same extent as in the public sector. Hence, they are more flexible in the choice of wholesalers and can also purchase directly from the producer. For the wholesaler, efficiency and reliability of the deliveries become important aspects of competitiveness (Ziggers \& Trienekens, 1999). The ability to collaborate with others could also be used to build up competitiveness. Partnerships in the food value network may be developed by interdependent firms that exchange information, people and resources in order to realize superior customer value.

\section{Results of Research}

The interviews with the catering and wholesaler organizations focused on four identified themes (geographical origin, production methods, product properties and delivery services) in order to determine their relative importance for the purchase decision (Appendix 1 provides more empirical details). A continued empirical analysis focused on identifying factors that are important for catering procurement of beef, with a particular interest in beef with added values. Conditions for procurement in the public and commercial catering are associated with a number of obstacles and opportunities in purchasing beef with added values (Table 2). 
Table 2. Procurement conditions, obstacles and opportunities for beef with added values.

\begin{tabular}{|c|c|c|}
\hline & Public catering & $\begin{array}{c}\text { Commercial catering } \\
\text { (á la carte/lunch segments) }\end{array}$ \\
\hline $\begin{array}{l}\text { Procurement con- } \\
\text { ditions for beef }\end{array}$ & $\begin{array}{l}\text { - Large volume } \\
\text { - Low prices } \\
\text { - Preferences for Swedish beef } \\
\text { - Forequarter carcass of beef } \\
\text { - Pre-cooked and ready cut beef } \\
\text { - Adjusted package sizes } \\
\text { - Few \& punctual deliveries } \\
\text { - Wide assortment wholesalers }\end{array}$ & $\begin{array}{l}\text { - Large volume to get even quality } \\
\text { - Varied price segments } \\
\text { - Preferences for imported beef } \\
\text { - Hind/forequarter of beef depending on prize } \\
\text { segment } \\
\text { - Use of raw materials or pre-cooked and } \\
\text { ready cut beef depending on prize segment } \\
\text { - Frequent \& flexible deliveries } \\
\text { - Specialized suppliers or wide assortment } \\
\text { wholesalers depending on profile }\end{array}$ \\
\hline $\begin{array}{l}\text { Obstacles for beef } \\
\text { with added values }\end{array}$ & $\begin{array}{l}\text { - Offered in small volumes } \\
\text { - Relatively high price } \\
\text { - Public procurement regulations limit the } \\
\text { ability to request beef of a certain geo- } \\
\text { graphic origin } \\
\text { - Lack of processed beef, where cooking } \\
\text { facilities and time for food preparations are } \\
\text { limited } \\
\text { - Lack of right package size, especially for } \\
\text { organic beef } \\
\text { - Inefficient distribution, especially of } \\
\text { organic beef } \\
\text { - Often provided by specialized suppliers, } \\
\text { where public procurement favour large } \\
\text { wholesalers }\end{array}$ & $\begin{array}{l}\text { - Offered in small volumes } \\
\text { - Relatively high price } \\
\text { - Current perceived lack of consumer demand } \\
\text { - Inefficient distribution of organic beef } \\
\text { - Swedish beef is sometimes perceived to } \\
\text { have less quality because of a too short } \\
\text { tenderizing period } \\
\text { - Often provided by specialized suppliers, } \\
\text { where some restaurants favour large wholesal- } \\
\text { ers. }\end{array}$ \\
\hline $\begin{array}{l}\text { Opportunities for } \\
\text { beef with added } \\
\text { values }\end{array}$ & $\begin{array}{l}\text { - Preference for Swedish beef } \\
\text { - Positive attitude towards organic food due } \\
\text { to governmental goal } \\
\text { - Possible to require organic beef as an al- } \\
\text { ternative \& supply information of geographi- } \\
\text { cal origin in the framework agreement } \\
\text { - Public procurement can get lower prices } \\
\text { due to large volumes } \\
\text { - Possible for suppliers to cooperate in } \\
\text { order to supply larger volumes } \\
\text { - Possible to divide the procurement } \\
\text { requirement into smaller volumes to include } \\
\text { smaller suppliers in the bidding } \\
\text { - Possible for smaller producing units to } \\
\text { cook from raw material }\end{array}$ & $\begin{array}{l}\text { - Food with added value provide grounds for } \\
\text { differentiation } \\
\text { - Á la carte restaurants use high quality beef \& } \\
\text { have no need for processed food } \\
\text { - Organic beef are perceived to have a high } \\
\text { quality } \\
\text { - Possible to use both hind and forequarter of } \\
\text { beef to get lower prices } \\
\text { - Possible for suppliers to cooperate in order to } \\
\text { supply larger volumes } \\
\text { - Strong relations to specialized suppliers can } \\
\text { help to guarantee volumes }\end{array}$ \\
\hline
\end{tabular}

The findings that are presented in Table 2 are more closely analyzed and discussed in the following analytical discussion. 


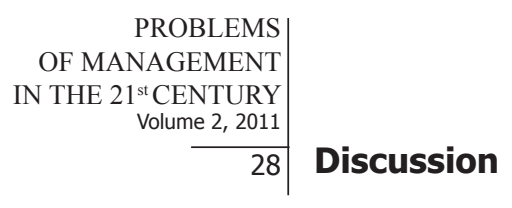

This study set out to analyze factors that influence the procurement of beef, with an interest to compare these factors between the commercial and public catering sector. The relation between a seller and a buyer is part of a value chain in a cultural, legal and social context. Added value is created in series of choices made along the way by many actors in the value chain (Figure 2). Some choices are conscientiously expressed in the procurement process (production methods, processing methods, product offer including deliveries and other services). Other choices are more tied to legal and political obligations. Grounds for adding value, which in turn may lead to differentiation, in the value chain for public and commercial catering are further discussed as conditions for production, processing and delivery and catering.

\section{Conditions for Production}

The organic production method serves as a strong basis for differentiation. It involves a third party control in the certification process and it also requires substantial investments for farmers that lead to economic bonds (Easton, 1992). Certifications, such as KRAV, can be used by farmers that are involved in direct marketing to achieve additional consumer trust, but can also be used to market their products more broadly (Higgins et al., 2008).

For the farmer, a condition for changing to organic methods is that it needs to represent a safe investment, which requires other actors in the value network to collaborate (Ziggers \& Trienekens, 1999). In this study, lacking large volumes was used as an argument for not buying organic and Swedish beef (Table 2), despite the fact that the full potential in Swedish and organic beef production is not utilized (Swedish Ecological Farmers, 2008). Partly, this situation is explained by a preference for delicate cuts by most commercial catering units where the forequarter carcass is less desirable, which on the other hand is preferred by the public catering units (App. 1).

Swedish consumers reveal a preference for Swedish food products (SOU, 2005) and a positive attitude towards organic food products (Magnusson et al., 2001). However purchasers in the commercial sector currently perceive a lack of consumer demand for both Swedish beef and organic beef. Professional purchasers tended to associate organic production with Swedish production standards, which points to the fact that local production is often integrated with organic production (Figure 2). The two production systems are interdependent in terms of legal enforcement (Easton, 1992), e.g. national regulations on animal welfare and food safety. However, the social bonds between the producer and catering organization seem stronger in organic production than Swedish conventional production. Due to the differentiated production method of organic beef, the structure of the organic beef value network is heterogeneous (Easton, 1992; Johanson \& Mattsson, 1992); withholding a limited number of actors who are involved in the production and processing of organic beef. This poses constraints on the ability to choose potential actors to collaborate with and creates interdependencies, which require the actors to gradually adjust to each other.

\section{Conditions for Processing and Delivery}

Grounds for differentiation (Ziggers \& Trienekens, 1999) in the processing and delivery are partly dependent on powerful actors controlling resources in the processing of beef (Figure 2). Technical bonds (Easton, 1992), in terms of tenderizing techniques, were found to play a crucial role for the final quality of the beef. Swedish beef was perceived not to be sufficiently tenderized, whereas the tenderizing of organic beef already is associated with high quality (Table 2). An increased period for tenderizing Swedish beef appears to be an opportunity for increased value of the product. 
The personal contact between sellers in wholesaler organizations and purchasers in catering organizations is important, since wholesalers are carriers of knowledge about the product properties and the connection to production method, geographical origin and processing (Inwood et al., 2009). This study observes that there is room for strengthening the communication with wholesalers, which could function as a social link between the producer and consumer. Strong social bonds are a condition for stability in the network of the supply chain (Easton, 1992). An opportunity for organic beef can be identified in preserving the local identity of the organic farms throughout the slaughtering process by strengthening the resource tied interdependencies (Figure 1) with actors further down the value chain.

\section{Conditions for Catering}

The procurement process sets the scene in a process that could be labelled as differentiation. The needs for the catering organizations, commercial as well as public, to differentiate the product offers vary. In commercial catering, a market segment is in part selected in the catering offer. Commercial catering businesses appear to have unlimited opportunities to differentiate their offers, and thereby select suitable market segments. In the public market, however, the alternatives for many customers (at schools, hospitals etc.) are limited. Since they often have only one restaurant to eat at, the choices in the procurement process are primarily related to ensuring health and dietary aspects while satisfying the budget constraint. Public catering is also more heavily influenced by political objectives that are defined on a national basis and as such do not serve as grounds for differentiation.

Professional purchasers play a key role in supplying the catering market with the perceived needs in order to accommodate to customers' preferences (Bergström et al., 2005; Grankvist \& Biel, 2007; Inwood et al., 2009). In both commercial and public catering organizations, the personal commitment of individual purchasers has shown to be an important factor that determines the profile of the catering organization (Inwood et al., 2009; Walker et al., 2008).

\section{Conditions in Public Catering}

Wholesale distribution to the public catering sector is characterized by few and punctual deliveries of a wide assortment of products (Table 2). It is also manifested in legally binding purchasing contracts that may last up to three years, which supports the notion of legal bonds (Easton, 1992). This practice tends to limit the competition for smaller scale companies that are unable to meet prize constrains as well as volume and delivery requirements (Swedish Competition Authority, 2008). There is an opportunity to let smaller scale companies enter the competition, such as organic and local suppliers, by dividing the procurement bid into smaller volumes (Table 2). It is also legally possible for smaller scale companies to cooperate by supplying a portfolio of complementary products that normally cannot be supplied in the required volumes by an individual firm.

Post et al. (2008) point to a dilemma in the public food sector in the choice between industrialized production systems and ideological concerns for organic food that is associated with using fresh raw materials. Commonly, public catering depends on ready-made meals from "central kitchens" since only a small number of catering units cook the food themselves. Therefore, most kitchens do not have the capacity to cook based on raw materials (Table 2). Nevertheless, some producing catering units cooked from raw material and used lesser amount of beef in order to afford beef with added value. They could thereby also more effectively reach the political goal. Opportunities to increase the use of food with added value could either be to increase the supply of ready-made food products in the requested package sizes, or to integrate the systems of producing and serving units in public catering (Delfi, 2006). 
PROBLEMS

OF MANAGEMENT

IN THE $21^{\text {st }}$ CENTURY

Volume 2, 2011

30

Legal restrictions and societal objectives influence the procurement conditions and thereby the development of a market for food with added values. For example political objectives have shown to be an important external influence (Pfeffer \& Salancik, 2003) and an opportunity for increasing the procurement of organic food in the public sector. On the other hand procurement with requests of the geographical origin is legally prohibited.

\section{Conditions in Commercial Catering}

Commercial catering may use added values in differentiating their offers. The procurement process presupposes quality, frequent deliveries and flexibility, for the restaurant to handle a competitive market. Restaurants select their consumers in strategic choices related to profile and price. These profiles may be related to one or several added values, such as geographical origin of the food, health or environmental concern (organically certified). Yet, the perceived lack of consumer demand for added values is given as a reason not to differentiate a catering business. But naturally, added values need to be marketed to consumers in order to make them aware of what differs the company from its competitors. This need for consumer awareness is identified by Arfini and Mancini $(2010,149)$. "Only when the end market is aware and properly informed can it reward credence goods through higher consumer willingness to spend". However, small food companies, often found in commercial catering, have previously shown weaknesses in their marketing management capabilities (Banterle et al., 2010).

The social bonds between the wholesaler, or supplier acting as an agent for the farmer, and the commercial restaurant with a profile towards food with added values has proven to be especially important (Inwood et al., 2009), where long term interactions characterized the relationship (Table 2). The need for strong social bonds can be an effect of the limited supply of beef with added values in the market. Organic certification showed to be less important for locally produced beef, where the interdependencies are well developed. However, the logistical bonds are weak. An opportunity for purchasing food with added value in larger scale could be to strengthen the distribution channels in collaboration with already established wholesalers as a step in market development. These findings are supported by Ziggers and Trienekens (1999) and Post et al. (2008). This would reinforce the need for a trusted certification with retained producer identity, since the direct social bonds would tend to weaken as the market grows (Higgins et al., 2008). Nevertheless, the current need for more efficient distribution channels remain, especially in the commercial restaurants that require flexible and frequent deliveries (Table 2).

\section{Conclusions}

In public catering the main obstacles in offering food with added values are associated with the professional purchasers' perceived nature of the procurement process, which is influenced by political goals, budget constraints and procurement legislation. Public procurement is characterized by long-term contracts, precise orders, large volumes and low prices. This limits the number of producers that may make an offer. Additionally beef with added values often comes in smaller volumes and at higher prices. Opportunities for food with added values in the public sector are mainly connected to political objectives.

In commercial catering the obstacles in offering beef with added values are also somewhat associated with the lack of large volumes and higher prices. Moreover lacking product properties (tender meat and particular cuts) along with ineffective distribution may also be important constraints. However, commercial catering has more options for differentiation given less legal constrains and private interests that determine the budget. The commercial market is also more exposed to competitive pressures which would support the opportunity to 
differentiate the offers. However, a differentiation strategy needs to be reinforced by marketing to the consumers.

The findings also show that procurement conditions for food products with added values are intimately tied to how the professional purchaser in the catering organization perceives consumer values. This study supports the notion of how personal values of the professional purchaser play a major role, given room to interpret the task, the objectives and the long-term strategy in the catering organization. Consumers are dependent on communication relating to values in the product offer as well as choices made to substantiate these values.

Suggestions for continued research include focusing on how political objectives influence the development of markets for products with various added values. The development of markets for organic products is especially interesting regarding political objectives and how they influence the public sector's own procurement. A practical matter of major importance, given the time constrains in most public and commercial kitchens, is that of the management of a product offer that is processed. What is needed? And offered? Last but not least, what are consumer perceptions of values in product offers and catering profiles? These questions may serve as starting points for continued studies.

\section{Acknowledgements}

The study has been financed by the Foundation for Strategic Environmental Research (Mistra) as part of the research program FOOD 21 (MAT 21) at SLU. The compilation of this article was also financed by The Swedish Research Council Formas.

\section{References}

Arfini, F., Mancini, M. C. (2010). Regulatory Framework and Private Innovation: The Case of Animal Welfare Friendly Beef Supply Chain in Italy. International Journal on Food System Dynamics, 2, 143150 .

Banterle, A., Carraresi, L., Stranieri, S. (2010). Small Business Marketing Capability in the Food Sector: The Cases of Belgium, Hungary and Italy. International Journal on Food System Dynamics, 2, 94-102.

Bergström, K., Solér, C., Shanahan, H. (2005). Professional food purchasers' practice in using environmental information. British Food Journal, 107, 5, 306-319.

Boland, M., Schroeder, T. (2002). Marginal Value of Quality Attributes for Natural and Organic beef. Journal of Agricultural and Applied Economics, 34, 1, 39-49.

Delfi (2006). Delfi Storhushållsguide 2006. Stockholm, Sweden, Delfi Marknadspartner AB \& Strömblad Management AB.

Easton, G. (1992). Industrial networks: a review. In B. Axelsson, G. Easton (Ed.), Industrial Networks - A new view of reality (pp. 1-27). London, Routledge.

Gellynck, X., Kühne, B. (2010). Horizontal and Vertical Networks for Innovation in the Traditional Food Sector. International Journal on Food System Dynamics, 2, 123-132.

Grankvist, G., Biel, A. (2007). The Impact of Environmental Information on Professional Purchasers' Choice of Products. Business Strategy and the Environment, 16, 421-429.

Grunert, K. G., Bredahl, L., Brunsø, K. (2004). Consumer perception of meat quality and implications for product development in the sector - a review. Meat Science, 66, 259-272. 
PROBLEMS

OF MANAGEMENT

IN THE $21^{\text {st }}$ CENTURY

Volume 2, 2011

32

Higgins, V., Dibden, J., Cocklin, C. (2008). Building alternative agri-food networks: Certification, embeddedness and agri-environmental governance. Journal of Rural Studies, 24, 15-27.

Inwood, S. M., Sharp, J. S., Moore, R. H., Stinner, D. H. (2009). Restaurants, chefs and local foods: insights drawn from application of a diffusion of innovation framework. Agriculture and Human Values, $26,3,177-191$

Johanson, J., Mattsson, L. G. (1992). Network positions and strategic action - an analytical framework. In B. Axelsson, G. Easton (Ed.), Industrial Networks - A new view of reality (pp. 205-217). London, Routledge.

KRAV (2009). Så här blir det ekologiskt nötkött! http://www.krav.se/sv/skola/Ekoskolan/ Fakta/Sa-blirdet/ekologiskt-notkott--/. Accessed 25 Mars 2009.

Krystallis, A., Chryssohoidis, G. (2005). Consumers' willingness to pay for organic food: Factors that affect it and variation per organic product type. British Food Journal, 107, 5, 320-343.

Li, L., Geiser, K. (2005). Environmentally responsible public procurement (ERPP) and its implications for integrated product policy (IPP). Journal of Cleaner Production, 13, 705-715.

Magnusson, M. K. Arvola, A., Koivisto Hursti, U. K., Åberg, L., Sjödén, P. O. (2001). Attitudes towards organic foods among Swedish consumers. British Food Journal, 103, 3, 209-226.

Mattsson, L. G., Johanson, J. (2006). Discovering market networks. European Journal of Marketing, 40, 3/4, 259-274.

Pfeffer, J., Salancik, G. (2003). The external control of organizations. A Resource Dependence Perspective. Stanford, Stanford University Press.

Pitta, D. A., Laric, M. V. (2004). Value chains in health care. Journal of Consumer Marketing, 27, 7 , 451-464.

Porter, M. (1985). Competitive Advantage: Creating and Sustaining Superior Performance. New York, The Free Press.

Post, A., Shanahan, H., Jonsson, L. (2008). Food processing: barriers to, or opportunities for, organic foods in the catering sector? British Food Journal, 110, 2, 160-173.

Robson, C. (2002). Real world research, 2nd ed. Oxford, UK, Blackwell Publishing.

SLV (National Food Administration) (2009). Swedish Food Regulations, Food Act 2006:804. http://www. slv.se/upload/nfa/documents/food_regulations/FoodAct2007.pdf?epslanguage=EN-GB. Accessed 25 Mars 2009.

SOU (Statens Offentliga Utredningar) (2005). Bilen, biffen, bostaden. Hållbara laster - smartare konsumtion. SOU 2005:51. Stockholm, Sweden, Edita Norstedts Tryckeri AB.

Swedish Board of Agriculture (2008). Consumption of food and nutritive values, data up to 2006. Statistikrapport 2008:1. http:/www.sjv.se/webdav/files/SJV/Amnesomraden/Statistik\% 2C\%20fakta/Livsmedel/2008\%3A1/2008 1.pdf. Accessed 25 Mars 2009.

Swedish Competition Authority (2005). Nordic Food Markets - a taste for competition. Avdelningen för ekonomisk analys, Lundvall K, Konkurrensverket. http:/www.kkv.se/upload /Filer/ENG/Publications/ rap_nordic_food_markets_summary.pdf. Accessed 25 Mars 2009. 
Hanna ASTNER, Ingrid STIGZELIUS, Hans ANDERSSON, Cecilia MARK-HERBERT. Managing Procurement of Food with Added Value: A Case Study of Beef in the Catering Sector

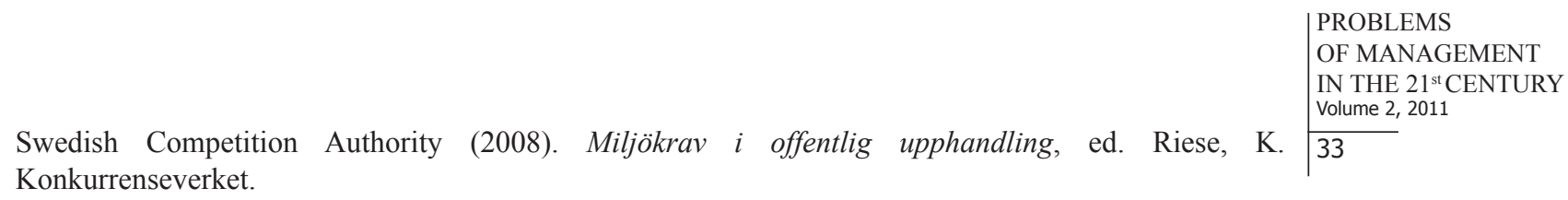

Swedish Ecological Farmers (2008). Växande marknad. Försäljning, volymer \& trender för ekologisk mat. Van der Krogt, D. and Larsson L. Ekologiska Lantbrukarna, Uppsala, Sweden.

Swedish Environmental Protection Agency (2007). Import av kött - export av miljöpåverkan. Rapport 5671, Februari 2007, Karl-Ivar Kumm and Malin Larsson. Naturvårdsverket, Stockholm, Sweden. http:// www.naturvardsverket.se/Documents/publikationer/620-5671-9.pdf.Accsessed21. Juni 2010.

Swedish Environmental Protection Agency (2008). Konsumtionens klimatpåverkan. Rapport 5903, November 2008. Naturvårdsverket: Stockholm, Sweden.

Swedish Government (2005). Ekologisk produktion och konsumtion - mål och inriktning till 2010. Regeringens skrivelse 2005:06:88, Stockholm, Sweden.

Turnbull, P., Ford, D., Cunningham, M. (1996). Interaction, relationships and networks in business markets: an evolving perspective. Journal of Business and Industrial marketing, 11, 3/4, 44-62.

Walker, H., Di Sisto, L., McBain, D. (2008). Drivers and barriers to environmental supply chain management practises: Lessons from the public and private sectors. Journal of Purchasing and Supply Management, 14, 69-85.

Walters, D., Lancaster, G. (1999). Value and information - concepts and issues for management. Management Decision, 37, 8, 643-656.

Ward, S., Webster F. E. Jr. (1991). Organizational Buying Behaviour. In T.S. Robertson and H.H. Kassarjian (Eds.), Handbook of Consumer Behaviour (pp. 419-457). Englewood Cliffs, NJ, Prentice-Hall.

Ziggers, G. W., Trienekens, J. (1999). Quality assurance in food and agribusiness supply chains: Developing successful partnerships. International Journal of Production Economics, 60-61, 271-279. 
PROBLEMS

OF MANAGEMENT

IN THE $21^{\text {st }}$ CENTURY

Volume 2, 2011

34

Appendix 1. Factors influencing the purchase of beef.

\begin{tabular}{|c|c|c|c|c|}
\hline ACTORS & Origin of product & $\begin{array}{l}\text { Production meth- } \\
\text { ods }\end{array}$ & Product properties & Delivery services \\
\hline \multicolumn{5}{|c|}{ Public catering } \\
\hline $\begin{array}{l}\text { Day care centers } \\
\text { purchasing or- } \\
\text { ganic products }\end{array}$ & $\begin{array}{l}\text { Preference for } \\
\text { Swedish }\end{array}$ & $\begin{array}{l}20-26 \% \text { organic } \\
\text { due to animal } \\
\text { welfare at transport } \\
\& \text { slaughter }\end{array}$ & $\begin{array}{l}\text { Buys mostly minced } \\
\text { and cubed meat. Firm } \\
\text { meat, no tendons } \\
\text { bones or grey colour, } \\
\text { smell/taste, ready cut } \\
\text { sizes, food safety }\end{array}$ & $\begin{array}{l}\text { Wide assortment, few } \\
\text { deliveries, personal } \\
\text { contact, right products }\end{array}$ \\
\hline Schools & $\begin{array}{l}\text { Preference for } \\
\text { Swedish because } \\
\text { of animal welfare \& } \\
\text { food safety. Some } \\
\text { thought that Ameri- } \\
\text { can meat have } \\
\text { higher quality. }\end{array}$ & $\begin{array}{l}\text { Cannot buy } \\
\text { organic due to } \\
\text { lack of volumes, } \\
\text { although they see } \\
\text { a connection with } \\
\text { animal welfare and } \\
\text { product quality }\end{array}$ & $\begin{array}{l}\text { Buys mostly minced } \\
\text { meat. Look at the } \\
\text { appearance, firmness, } \\
\text { no tendons, bones } \\
\text { or collagen, smell, } \\
\text { durability }\end{array}$ & $\begin{array}{l}\text { Price, package size, } \\
\text { wide assortment, food } \\
\text { safety, punctuality, right } \\
\text { temperature and prod- } \\
\text { ucts when delivered }\end{array}$ \\
\hline $\begin{array}{l}\text { Schools purchas- } \\
\text { ing organic } \\
\text { products }\end{array}$ & $\begin{array}{l}\text { Preference for } \\
\text { Swedish }\end{array}$ & $\begin{array}{l}35 \% \text { organic \& } \\
\text { only organic meat } \\
\text { due to animal wel- } \\
\text { fare and support } \\
\text { of grazing cattle \& } \\
\text { connection to meat } \\
\text { quality }\end{array}$ & $\begin{array}{l}\text { Organic important, } \\
\text { but should never be } \\
\text { prioritized before qual- } \\
\text { ity. Uses as much raw } \\
\text { food as possible }\end{array}$ & $\begin{array}{l}\text { Assurance of sufficient } \\
\text { organic volumes. } \\
\text { Deliveries according to } \\
\text { contract. }\end{array}$ \\
\hline Homes for elderly & $\begin{array}{l}\text { Preference for } \\
\text { Swedish because of } \\
\text { animal welfare, food } \\
\text { safety and support } \\
\text { of the Swedish } \\
\text { agriculture }\end{array}$ & $\begin{array}{l}\text { Rarely buys or- } \\
\text { ganic meat due to } \\
\text { budget constraints } \\
\text { and lack of interest } \\
\text { from the consum- } \\
\text { ers }\end{array}$ & $\begin{array}{l}\text { Buys most pork, but } \\
\text { also minced, cubed } \\
\text { and sometimes more } \\
\text { delicate beef cuts. } \\
\text { Look for firm meat } \\
\text { with no tendon or } \\
\text { collagen, even quality } \\
\& \text { size }\end{array}$ & $\begin{array}{l}\text { Right products, price, } \\
\text { punctuality, wide as- } \\
\text { sortment with varied } \\
\text { package sizes, few } \\
\text { deliveries, varied } \\
\text { preference for personal } \\
\text { contact \& internet use }\end{array}$ \\
\hline \multicolumn{5}{|c|}{ Commercial catering } \\
\hline Lunch & $\begin{array}{l}\text { Does not affect } \\
\text { purchase decision, } \\
\text { buys mostly from } \\
\text { Europe and South } \\
\text { America. One unit } \\
\text { buys Swedish } \\
\text { due to consumer } \\
\text { demand }\end{array}$ & $\begin{array}{l}\text { Does not affect } \\
\text { purchase decision }\end{array}$ & $\begin{array}{l}\text { Buys cubed sized, } \\
\text { minced and some deli- } \\
\text { cate beef cuts. Two } \\
\text { unit cuts from whole } \\
\text { pieces to guarantee } \\
\text { quality. Looks for } \\
\text { fresh, tender meat } \\
\text { with dark red colour in } \\
\text { good cuts }\end{array}$ & $\begin{array}{l}\text { Price, product quality, } \\
\text { wide assortment, good } \\
\text { contact, flexibility, de- } \\
\text { liveries two-three times } \\
\text { a week, one unit had } \\
\text { deliveries everyday }\end{array}$ \\
\hline Á la carte & $\begin{array}{l}\text { Origin does not } \\
\text { affect decision }\end{array}$ & $\begin{array}{l}\text { Rarely buys organ- } \\
\text { ic due to high price } \\
\text { and lack of interest } \\
\text { from consumers }\end{array}$ & $\begin{array}{l}\text { Mainly buys fillet of } \\
\text { beef, entrecote etc. } \\
\text { Looks for firm meat, } \\
\text { tender/well hung, } \\
\text { marbled with a cap, } \\
\text { well cut, even quality. } \\
\text { Cooks mainly from } \\
\text { raw materials }\end{array}$ & $\begin{array}{l}\text { Use both wholesalers } \\
\text { and fresh produce sup- } \\
\text { pliers. Product quality, } \\
\text { sufficient volumes, } \\
\text { price/bonuses, trust/ } \\
\text { contact, flexibility, fast } \\
\text { deliveries }\end{array}$ \\
\hline
\end{tabular}


Hanna ASTNER, Ingrid STIGZELIUS, Hans ANDERSSON, Cecilia MARK-HERBERT. Managing Procurement of Food with Added Value: A Case Study of Beef in the Catering Sector

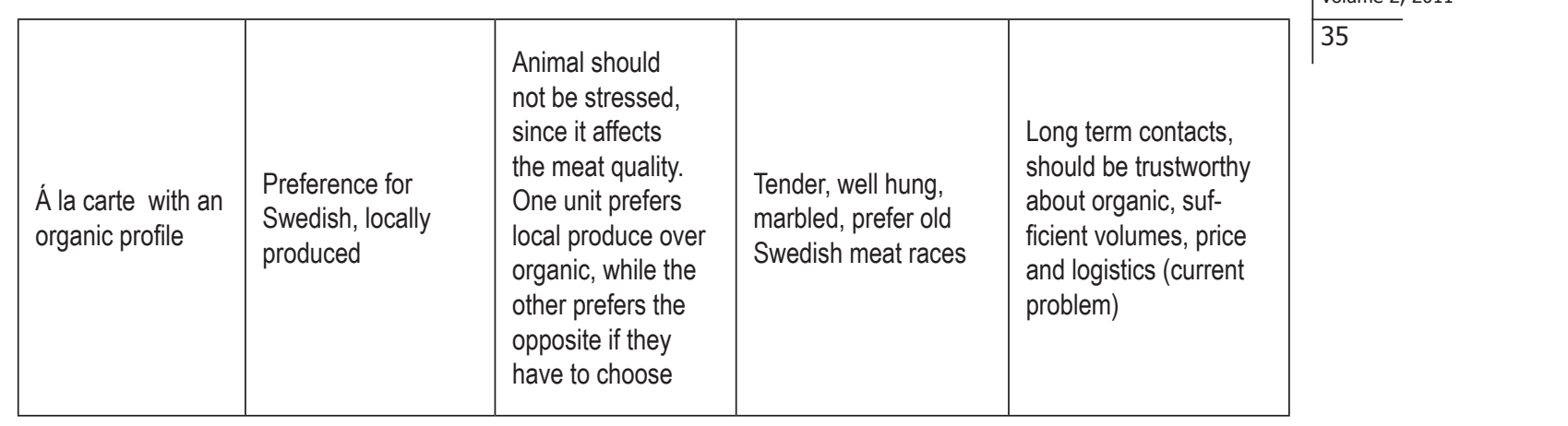

Advised by Vincentas Lamanauskas, University of Siauliai, Lithuania

Received: September 15, 2011

Accepted: October 28, 2011

\begin{tabular}{|ll|}
\hline Hanna Astner & Msc, PhD Student, Swedish University of Agricultural Sciences, Depart- \\
ment of Economics, P.O. Box 7013, 75007 Uppsala, Sweden. \\
E-mail: Hanna.Astner@slu.se \\
Website: http://www.slu.se/ekonomi
\end{tabular}

